\title{
Spanish teaching students' attitudes towards teaching science at the pre-school level
}

\author{
Jiménez-Tejada, M. P. ${ }^{\text {la }}$, Romero-López, M. C. ${ }^{1}$, Almagro-Fernández Agnès ${ }^{1}$, M., \\ González-García, F.1 and Vílchez-González, J.M. ${ }^{1}$ \\ ${ }^{1}$ Department of Didactics of Experimental Sciences, Faculty of Education Sciences, University of \\ Granada, E-18071 Granada, Spain DP Sciences, Editorial Department, 91944 Les Ulis Cedex A, \\ France
}

\begin{abstract}
Previous researches on early childhood teachers' attitudes toward science teaching reveals that they feel anxiety and fear regarding science classes. Sometimes, teaching students' experience with science have a significant influence on their attitude toward science and science teaching. This prior experience has been frequently joined to remember abstract concepts, and it determine what they guess about science teaching in early childhood. In order to assess teacher trainee's pre-existing attitudes and beliefs toward science teaching in early years, we used a preschool teachers' attitudes and beliefs toward science teaching questionnaire developed and validated for Maier, Greenfield and Bulotsky-Shearer (2013). Aspects such as science knowledge or ability to create sciencerelated activities, at the beginning, are very poorly valued by future teachers of early childhood education. The main reason is the poor knowledge that they have about science in general. We can conclude that it is important that future teachers of early childhood education should understand importance to teach science to children.
\end{abstract}

\section{Introduction}

It is a fact that the sciences and technology are present in our everyday life both at a small scale as in the case of our homes (kitchen, cleaning products, electric systems, etc.), as well as a on a large scale in universities, companies linked to science and technology or medicine. The interest that science stirs in the society is such that the news media report the latest advances in science through popular-science programmes. But we might ask: Why all the interest? On the one hand, industrialized societies as well as developing countries need the support of these advances to continue progressing, and on the other hand, the scientific and technological community require the recognition of a society which is ever more critical and involved in decision making, and that with their donations and/or taxes finance the professional activity of these communities. It is not strange, then, that

\footnotetext{
a Corresponding author: pjtejada@ugr.es
} 
governments strive to project a good image of both in society. However, despite this interest of the society and government in science, in fact fewer young people are going into science, reflecting the low interest that this group shows for science and technology. Different authors have suggested that behind this low trend of going into science is a lack of interest towards science and technology [5 and 20]

The attitude towards the sciences is uneven throughout the educational stage. Osborne, Driver, and Simon [12] revealed that interest in the sciences develops at early ages; however, this interest significantly declines at 10 years old [10 and 12]. Apart from age, teaching quality is one of the factors that most influences participation and success of students in subjects related to science $[12,13,17$ and 21]. Teaching practices, the characteristics of the teachers or even teacher expectations of the students determine the quality of the teaching. At the infantile stage of education, we must add the attitude of the instructor towards teaching science. At this stage, teachers often do not feel comfortable teaching sciences and therefore there is little classroom work in this regard.

After a review of earlier studies, Erden and Sönmez [3] indicated that the arguments presented by teachers not to teach sciences at the infant stage vary, including the teachers' low confidence in their own mastery of the subject, the lack of proper space and materials, or the belief that it is not important to teach science at this stage. Before facing the teaching of science to infants, we should ask whether students at this stage have the abilities necessary to take on this task. However, this is a controversial issue with no consensus [14]. It is not surprising that some teachers believe that young children do not have the abilities necessary to learn science successfully.

What is the situation of future generations of pre-school teachers? In different Spanish universities, the students of pre-school teaching have a distinct profile. Most are women who quit studying science after finishing the third course of mandatory education. In the case the University of Granada, students claim at the beginning of the course not to like sciences and "to be from Humanities". Their prior experience with sciences is often limited to memorizing facts presented by the professor, and therefore their attitude towards science teaching at the infant stage is hardly propitious.

Given that the current generations of teaching students will be in charge of teaching future citizens, it is fundamental to know their attitudes towards teaching sciences at the infant stage, in order to design and plan childhood education properly. This was the main reason why at the beginning of the 2013/2014 course, the participation of teaching students was requested for the present study. The study was meant to:

a) determine the degree of self-confidence of teaching students in order to present science practices, to use scientific methodology and instruments;

b) identify the main obstacles that teaching students might have in managing scientific activities in the pre-school classroom;

c) ascertain whether teaching students appreciate the benefits of teaching science in preschool

\section{Materials and Methods}

To assess a teacher trainee's pre-existing attitudes and beliefs towards science teaching in the early years, we used a questionnaire on pre-school teachers' attitudes and beliefs towards science teaching, developed and validated by Maier, Greenfield, and BulotskyShearer (2013). We modified the questionnaire and changed the verb tenses to adapt it to student teachers. All items in this questionnaire were rated on a five-point Likert scale ranging from "strongly disagree" to "strongly agree". 
The questionnaire was administered to collect data at the start of the second semester of the last academic year (2013/14) and it included items for evaluating several aspects related to teacher comfort, child benefit, and challenges for teaching science.

A total of 231 questionnaires were completed and returned anonymously. The participants in this study were all female.

\section{Results and Discussion}

\subsection{Teaching students' self-confidence in their skills for offering science activities in pre-school}

Different studies have shown that the attitude shown by boys towards science in school is more positive than for girls $[15 ; 20]$. It is not surprising that females should feel a certain insecurity in their professional work in the future (Table 1 shows the percentages for the three disciplines: life, earth and physical and energy science). The fact that females feel more insecure when faced with activities in physics than with biology, or earth sciences, is consistent with the finding that differences according to gender are more evident for the physical sciences [11]. These results confirm an attitude among girls, which is more positive towards the biological sciences and health than towards the physical sciences, as reported in other studies [2, 9 and 20].

The present study reveals a certain parallel between the results found for evaluating the confidence in activities in physics and those for the evaluation of confidence in speaking about the scientific method. Easlea (1986) suggested that students could see a number of characteristics in physics that could dissuade girls from choosing this subject, as for instance a scant alteration of the scientific method. It is possible that individuals who do not show confidence in speaking about scientific methodology think about the possible difficulties of applying it to the pre-school classroom, and this could discourage them from using it.

Table 1. Answers to the questionnaire by student teachers on the attitudes and beliefs towards science teaching in the early years. Figures are percentages

\begin{tabular}{lccc}
\hline & $\begin{array}{c}\text { Agree/ } \\
\text { strongly } \\
\text { agree }\end{array}$ & $\begin{array}{c}\text { Neutr } \\
\text { al }\end{array}$ & $\begin{array}{c}\text { Disagree/ } \\
\text { strongly } \\
\text { disagree }\end{array}$ \\
\hline $\begin{array}{l}\text { I feel comfortable planning and demonstrating classroom } \\
\text { activities related to life science topics (n=231) }\end{array}$ & 74,9 & 17,8 & 7,4 \\
$\begin{array}{l}\text { I feel comfortable planning and demonstrating classroom } \\
\text { activities related to earth science topics }\end{array}$ & 74,8 & 19,1 & 6,1 \\
$\begin{array}{l}\text { I feel comfortable planning and demonstrating classroom } \\
\text { activities related to physical and energy science topics (n=231) }\end{array}$ & 38,5 & 39,4 & 22,1 \\
$\begin{array}{l}\text { I feel uncomfortable talking with young children about the } \\
\text { scientific method (n=230) }\end{array}$ & 27,4 & 36,5 & 36,1 \\
$\begin{array}{l}\text { I feel uncomfortable using scientific tools such as scales, } \\
\text { rulers, and magnifying glasses when teaching science lessons } \\
\text { (n=231). }\end{array}$ & 14,2 & 24,7 & 61,7 \\
$\begin{array}{l}\text { I will be afraid that children may ask me a question about } \\
\text { scientific principles or phenomena that I cannot answer } \\
\text { (n=229). }\end{array}$ & 40,1 & 59,9 & 0 \\
$\begin{array}{l}\text { I do not have enough scientific knowledge to teach science to } \\
\text { young children. (n=228) }\end{array}$ & 46,5 & 33,3 & 20,2 \\
$\begin{array}{l}\text { I will not have enough materials to do science activities } \\
\text { (n=230) }\end{array}$ & 15,6 & 44,8 & 39,6 \\
\hline
\end{tabular}




\begin{tabular}{|c|c|c|c|}
\hline $\begin{array}{l}\text { Planning and demonstrating hands-on science activities is a } \\
\text { difficult task }(n=230) \text {. }\end{array}$ & 38,3 & 45,7 & 16 \\
\hline $\begin{array}{l}\text { Science-related activities are too difficult for young children } \\
(\mathrm{n}=229) \text {. }\end{array}$ & 7,4 & 27,9 & 64,6 \\
\hline $\begin{array}{l}\text { It is not appropriate to introduce science to children at an early } \\
\text { age }(n=230) \text {. }\end{array}$ & 4,8 & 14,8 & 80,4 \\
\hline $\begin{array}{l}\text { Young children are curious about scientific concepts and } \\
\text { phenomena }(n=230) \text {. }\end{array}$ & 86,1 & 11,3 & 2,6 \\
\hline $\begin{array}{l}\text { Science-related activities help improve preschoolers' } \\
\text { approaches to learning }(\mathrm{n}=230) \text {. }\end{array}$ & 59,1 & 39,1 & 1,7 \\
\hline $\begin{array}{l}\text { Science-related activities help improve preschoolers' social } \\
\text { skills }(n=229) \text {. }\end{array}$ & 51,1 & 43,7 & 5,2 \\
\hline $\begin{array}{l}\text { Science-related activities help improve preschoolers' language } \\
\text { skills }(\mathrm{n}=231)\end{array}$ & 30,7 & 61 & 8,2 \\
\hline
\end{tabular}

The same does not occur with the use of scientific instruments (Table 1). As the use of scientific instruments is not frequent even in secondary school and what is used is not especially complex, female teachers do not appear to feel any special lack of confidence.

A high percentage of students show discomfort regarding questions that their students could ask. Often, teaching students claim to have little knowledge of science, and therefore it is not rare for them to feel uneasy when faced with questions posed by their future students. According to different authors [3, 7 and 8], pre-school teachers claim not to have sufficient knowledge in science. The lack of knowledge in the discipline can prompt insecurity concerning possible questions. In fact, some teachers, in the study by Torquati, Cutler, Gilkerson, and Sarver [16], indicate that to master basic knowledge enables teachers to anticipate possible questions of their students.

\subsection{The opinions about challenges and difficulties of teaching science in pre- school}

Almost half of the female teaching students claim not to have sufficient scientific knowledge, feeling this to be a severe obstacle for the teaching of sciences, not only for students going into teaching but also for the teachers of pre-school, who have expressed this lack in the different studies mentioned above.

The students participating in the present study had not yet received training on how to teach sciences at the pre-school level, and therefore did not know whether the planning of activities in science would be complex, would require a great deal of time, or would require many materials. It is not surprising that the greatest percentage of responses fell into the neutral category.

Especially noteworthy was the opinion of the students on the difficulty of the activities in science in the pre-school stage and on whether such activities were appropriate for this stage. In both cases, a high percentage showed a positive attitude towards teaching science at this stage, despite showing an initial rejection of this subject. Although the questionnaires were anonymous, it was possible that some students were not completely candid in their responses. As the poll was taken at the beginning of the subject of sciences and its teaching for pre-school, this class may have influenced the outcome of the poll.

\subsection{The thinking towards science and its relationships with the improvements of several skills: approaches to learning, math, language, and social skills, etc.}


On examining the activities undertaken by boys and girls at the pre-school stage, we can appreciate their facility to be surprising, to ask about the causes behind what happens, to probe and to verify. This capacity to surprise was appreciated by a rather high percentage of the teaching students, although it was striking that some students maintained a neutral opinion. The innate curiosity to enjoy nature is one of the reasons for which we cannot renounce the teaching of science at this stage. Pre-school teachers should not refuse to teach sciences at this stage if they wish to preserve this capacity of children to be surprising [4]. However, this is not the only reason to teach science at this stage. Different studies have indicated that during the learning of sciences, numerous abilities are acquired. Thus children that participate in the project Science Start! showed less negative behaviour, improved their lack of attention, learned and participated more, acquired new vocabulary, and increased their linguistic abilities [6]. Similar results were also reported by Samarapungavan, Mantzicopoulos, and Patrick [14] after a session on the life cycle of the monarch butterfly.

A rather high percentage of our teaching students positively evaluated some of these benefits, such as the improvement in learning and social abilities. However, only a small percentage of students appreciated the relation between sciences and linguistic abilities. We believe that this opinion could have been influenced by the traditional belief that the sciences and the humanities are unrelated.

\section{Conclusion}

It is necessary for future teachers of early-childhood education to understand the importance to teaching science to children. These teachers need to improve their sciencerelated knowledge. The role of the university professor is essential to ensure and improve the training these future teachers. By knowing the attitudes of the students towards science teaching, the professor will be able to take this information into account when organizing academic activities.

\section{Acknowledgements}

Funding was provided by the group HUM613 of the Universidad de Granada.

\section{References}

1. Chang, S. N., Yeung, Y. Y., \& Cheng, M. H. (2009). Ninth graders' learning interests, life experiences and attitudes towards science and technology. International Journal of Science Education and Technology, 18, 447-457.

2. Elster, D. (2007). Student interest: the German and Austrian ROSE survey. Journal of Biological Education, 42(1), 5-11.

3. Erden, T. E., \& Sönmez, S. (2011). Study of Turkish preeschool teachers'attitudes toward science teaching. International Journal of Science Education, 33(8), 1149-1168.

4. Eshach, H., \& Fried, M. N. (2005). Should science be taught in early childhood? Journal of Science Education and Technology, 14(3), 315-336.

5. Fensham, P. J. (2004). Beyond Knowledge: Other Outcome Qualities for Science Education. In: R. M. Janiuk \& E. Samonek- Miciuk (Ed.), XIth Symposium Proceedings, International Organization for Science and Technology Education (IOSTE), 25-30 July. 
6. French, L. (2004). Science as the center of a coherent, integrated early childhood curriculum. Early Childhood Research Quarterly, 19, 138-149.

7. García, M., \& Domínguez, R. (2011). La enseñanza de las ciencias naturales en el nivel inicial. Propuestas de enseñanza y aprendizaje. Homosapiens ediciones. Santa Fé, Argentina.

8. Hallam, S., \& Ireson, J. (2003). Secondary school teacher's attitudes towards and beliefs about ability grouping. British Journal of Educational Psychology, 73, 343-356.

9. Jones, M. G.; Howe, A. y Rua, M. J. (2000). Gender diferences in students' experiences, interest and attiutdes toward science and scientist. Science Education, 84, 180-192.

10. Murphy, C., \&Beggs, J. (2005). Primary science in the UK: A scoping study (Final Report to the Wellcome Trust). London: Wellcome Trust.

11. OECD Organisation for Economic Co-operation and Development. (2006). Evolution of Student Interest in Science and Technology Studies. Policy Report. Last view May 16, 2015 from www.oecd.org/dataoecd/16/30/36645825.pdf

12. Osborne, J., Driver, R., \& Simon, S. (1998) Attitudes to science: issues and concerns. School Science Review, 79 (288), 27-33.

13. Rivkin, S., Hanushek, E. A., \& Kain, J. (2005). Teachers, school, and academic achievement. Econometrics, 73, 417-458.

14. Samarapungavan, A., Mantzicopoulos, P., \& Patrick, H. (2008). Learning Science through inquiry in kindergarten. Science Education, 92, 868-908.

15. Sjøberg, S., \& Schreiner, C. (2005). Young people and science. Attitudes, values and priorities. Evidence from the ROSE project. Keynote presentation at EU's Science and Society Forum 2005. Session 4: How to foster diversity, inclusiveness and equality in science. Bruselas, European Union.

16. Torquati, J., Cutler, K., Gilkerson, D., \&Sarver, S. (2013). Early childhood educators' perceptions of nature, science and environmental education. Early Education and Development, 24, 721-743.

17. Tytler R., \& Osborne, J. (2012). Student attitudes and aspirations towards science. In Second International Handbook of Education. Springer Science+Business Media B. V.

18. Vázquez, A., \& Manassero, M. A. (2004). Imagen de la ciencia y la tecnología al final de la educación obligatoria. Cultura y Educación, 16(4), 385-398.

19. Vázquez, A., \& Manassero, M. A. (2006). Los intereses curriculares en ciencia y tecnología de los estudiantes de secundaria. Islas Baleares: Universitat de les Illes Balears y Conselleria d'Educació y Cultura de les Illes Balears.

20. Vázquez, A., \& Manassero, M. A. (2009). La relevancia de la educación científica: actitudes y valores de los estudiantes relacionados con la ciencia y la tecnología. Enseñanza de las ciencias, 27(1), 33-48.

21. Wayne, A., \& Youngs, P. (2003). Teacher characteristics and student achievement gains: A review. Review of Educational Research, 73, 89-122. 